\title{
THE USE OF THE CLASSTIME PLATFORM IN THE CONTEXT OF INCLUSION
}

\author{
Liudmyla Sydoruk,
}

a postgraduate student of Pedagogy and Management of Educational Establishment department at the Kamianets-Podilskyi Ivan Ohiienko National University, a mathematician of the department of information activity, archives and records management and fundamental disciplines at the Podilia educational and rehabilitational college of social sciences and conomics

https://orcid.org/0000-0002-4970-5197, e-mail: 1_sudoryk@ukr.net

\begin{abstract}
.
Relevance: the need to provide equal rights and create opportunities for the education of individuals with different educational needs at all educational levels including higher education as well. It is stated that the issues of realization of education continuity and lifelong learning have resulted the need for scientific, methodological and technical support of the educational process of higher education institutions in the conditions of inclusion.

The purpose: the article analyzes the possibilities of the modern Internet resource - Classtime, online platform which was created to adapt the process of teaching mathematics according to the individuals' needs and opportunities of higher education students in the conditions of inclusion.

Methods: analysis, synthesis and generalization.

Results. After having used the Classtime platform it has been determined that this service improves the quality of mathematics training for students' higher education in inclusion and has several benefits for both teachers and students. The resource offers a wide opportunity to analyze each student's learning activities and achievements, identifies the need for additional explanation and correction by the teacher depending on the actual state of material learning. Classtime platform is claimed to adapt the process of teaching mathematics to specific educational needs and to implement an individual approach to all higher education students by partially compensating for functional limitations caused by certain diseases, for example, for visually impaired people increasing the size of text to the proper size, for people with hearing impairments - the maximum visualization of the test, for people with disorders of the musculoskeletal system - the opportunity to focus more on the pre task activity, due to the simplicity of right answer choice and no need to write it.

Conclusions. Finally it is stated that scientifically proven and pedagogically aimed usage of modern Internet resources will allow students to fully participate in the educational process and create conditions for the implementation of their individual educational projects. The further perspective is to develop a methodology for mathematics teaching in the conditions of inclusion using information and communication technologies and to provide appropriate educational and methodological support.
\end{abstract}

Keywords: information and communication technologies; Internet resources; mathematical preparation; higher education; inclusive teaching; individual needs and abilities.

Introduction. New technologies have become an integral part of society and everyone's life in particular. And when a society is able to meet its needs in various fields using the capabilities and services, provided by specially trained professionals, then an individual can rely only on his/her own strength and abilities which are different in each person.
One of the priorities of the state (Ukrainian) policy in education is to ensure equal rights and create opportunities for the education of students with different educational needs at all educational levels, including higher education as well. The issues of implementing in education system that provides continuity and lifelong learning have resulted in the need for a going 
support which is scientific, methodological and technical of the educational process of higher education institutions (HEI) in the conditions of inclusion. The organization of inclusive education in HEI is carried out in accordance with the Decree of Ukraine Cabinet of Ministers No. 635 (July 10th, 2019) “On approval of the Procedure for the organization of inclusive education in higher education institutions". At the present stage the educational process of students with psychological and physical disabilities requires the development of appropriate materials educational and methodological and alongside the usage of information and communication technologies (ICT).

ICT usage improves the quality of education and also ensures accessibility and implementation of equal rights for all citizens to obtain education. The inclusive focus of ICT in the process of studying mathematics courses are obvious as mathematics training is an important component of training competitive and competent professionals for the labor market.

Sources. Some scholars and scientists, who have studied the problems of improving mathematical preparation through implementation of ICT include: V. Bykov, S. Velychko, M. Zhaldak, Y. Tryus, S. Semerikov, K. Slovak, O. Spivakovsky, K. Osadcha, I. Salnyk, O. Shavaliova. The issues related to the inclusion in Ukraine's higher education system and the support of students with special needs, were highlighted in the scientific works by V. Bondar, I. Ivanova, I. Kalinichenko, A. Kolupaieva, K. Kolchenko, H. Nikulina, L. Serdiuk, P. Talanchuk, H. Boyko, A. Kisliak, S. Misiak, V. Shyian. The analysis of the scientific achievements of domestic scientists shows the lack of well-developed approaches and methods for ICT implementation concerning inclusion in the processes of mathematics training of HEI students. The outlined problems initiate the necessity to provide appropriate scientific, technical and methodological support.

The aim of the paper. The article analyzes the possibilities of the modern Internet resource - Classtime, online platform which was created to adapt the process of teaching mathematics according to the individuals' needs and opportunities of higher education students in the conditions of inclusion.

The defined purpose demands the following tasks to be solved:

- characterize the peculiarities of mathematics training in HEI;

- identify ICT benefits of supporting inclusive learning/teaching;

- review other platform peculiarities of modern Internet resources;

- explore Classtime platform capabilities and highlight the benefits of its usage in the educational process.
Methods: the research methods, analysis and synthesis - to find out the state and level of problem investigation which is being studied; generalization - to formulate conclusions regarding the specifics of different functional limitations of higher education students and to create conditions for the realization of their individual educational trajectories through Classtime service.

Results and discussion. Teaching mathematics in HEI is characterized by a high level of complexity of learning material and abstractness of the subject, which requires considerable mental fortitude in mastering theoretical knowledge and practical skills. Teaching the subject requires a constant control over the logical presentation of new information, also it demands high attentive concentration, self-control, self-discipline, and the ability to share knowledge and finding with other students (Nosenko, 2018, pp. 199). However, due to inappropriate level of mathematics training at the previous stages of education, the other health problems during studying that caused attending less classes and combining learning and medical rehabilitation, all these facts create obstacles for people with disabilities. So there is a great necessity to adapt the educational process to their abilities, needs and opportunities.

The mathematics training quality in HEI, although the research concerns colleges, is exacerbated by the fact that students who complete a comprehensive secondary education, in accordance with the order of Ukraine Ministry of Education and Science No. 931 about "Some Issues of External Independent Assessment in 2019 the results of studies obtained on the basis of a complete general secondary education ", must be compiled by the state final certification in mathematics in the form of external independent assessment (EIT).

In order to improve the efficiency and quality of the mathematics learning process, it is advisable to use ICT, it enables to broaden and deepen the content of learning, it increases the clarity of learning material and it facilitates its perception through compact and clear presentation of educational information. ICT combines the students' learning motivation.

ICT usage also contributes to the activation of students' psychological physiological mechanisms:

- process of attention - individual approach and individual work involvement;

- process of perception - raising the emotional condition;

- process of memorizing - repetition and reflection on one's actions;

- process of abstract thinking - introduction of visual aids (Semerikov and Slovak, 2011).

Researcher Y. Nosenko, considering modern ICT support tools for inclusive learning, highlights the 
following advantages (Nosenko, 2018, pp. 28):

- expanding student autonomy;

- reducing communication difficulties and barriers;

- presenting learning outcomes in a convenient way;

- development of educational tasks taking into account individual skills and abilities of students;

- accessing training information independently;

- pacing task for students' capabilities;

- using ICT as a compensatory tool accessing educational information in an alternative way;

- exchanging experience within teachers in terms of inclusion;

- supporting teacher's ICT skills to support effective work with students;

- expanding opportunities for preparation of learning materials, and teaching aids;

- simplifying the adaption of materials in digital format to meet the students' needs.

The practice of using up-to-date informational mathematical Internet resources demonstrates a significant improvement of the students' knowledge levels, which allows to provide information technology support and guidance of certain stages of inclusive learning. These resources are divided into the following groups: mass open source systems, adaptive learning platforms, video channels, mathematical online simulators, online mathematics tasks, mathematical online platforms, mathematical online environments, mathematical services, mathematics mobile applications, mathematics training sites etc.

Researchers have shown that there are thematic resources for mathematics in mass open learning systems, resources for implementing adaptive mathematics learning, watching videos, training math skills, solving math problems from different sections of mathematics, game activities, and for combining different educational activities services in one resource, providing a large number of diverse tasks for the development of logical thinking, the creation of dynamic mathematical models, the search and creation of interactive training materials in mathematics. Also there are mathematics applications that can be used from a mobile phone (smartphone) or tablet computer, as well as online theoretical and methodological resources containing methodical and didactic materials (Osadcha, 2017, pp. 39).

Enormous opportunities to support inclusive learning/teaching are opening up due to the intensive development of ICT, which is facilitating the emergence of new Internet resources. One of such services is Classtime online platform, which allows the teacher to perform knowledge testing based on the individual approach to each higher education student.

Having Ukrainian interface, the resource is understandable and accessible for using even with a minimum level of ICT skills. The service has an archive of test tasks and allows the teacher to find questions on any topic, so that there is an experience exchange between educators. The platform also provides the importation of all EIT sessions in mathematics tasks that, in our opinion, creates the conditions for effective preparation of students for the state final assessment in the form of EIT.

Classtime platform allows you to create your own group of questions using the following types of test tasks: selecting one or more correct answers, matching or sequencing, writing or text sampling, defining whether the statement or image is true. The service also allows you to add explanations, pictures and videos.

For testing the teacher must select a group of questions and start the session, making its settings (Fig. 1) according to the purpose (training, diagnostics, knowledge control, etc.).
Mix answer options (Show the answer option in different order to each student)

Mix questions (Show the $\equiv_{x}$ questions in different order to each student)

Show answers at once (Show

Q the correct answer after each question)

One attempt only (Students can not alter their answers)
Turn on partial assessment (Let proportional grade be in points for partially correct answers)

Turn on step-by-step mode (Show the next question solely in the strict order)

Authorization is only through

Google/Microsoft (Students sign in for the session only through their Google accounts. Nicknames are not allowed)

v Reflection (Activate it to get students' feedback on the lesson at the end)

Time limit (Students have a time limit for

(c) answering all questions) $0 \mathrm{~min}$

Fig. 1. Session settings 
The possibility to mix questions and answer options, showing them to each student in different order, allows you to perform the same tasks for all participants of the test, which provides individu-alization of knowledge control, objectivity of assessment, creating a fair field for all higher education students.

In self-control tests students can see if the answer is correct after each question and modify it by tracing their own educational route.

The step-by-step setting method shows the next test question clearly and performs front-end testing.

In terms of individual characteristics, it is important to be able to determine the duration of testing since students with disabilities need more time to complete the tasks than healthy higher education students.

Students are required to sign in at https://www. classtime.com by entering a session code, last name and first name to complete the test from a smartphone or other gadget.

Using Classtime platform allows the teacher to see the test results online (Fig 2), which allows you to quickly assess the level of understanding and progress of each student individually and the whole group in general after having explained new material at the stage of generalization and systematization of knowledge.

Upon completion of the test, the platform allows you to download a report of the results of testing as a whole by group (Fig. 3) and for each task, in particular in different file formats PDF (Fig. 4) and Excel (Fig. 5), which significantly improves the effectiveness of monitoring student learning activities and achievements.

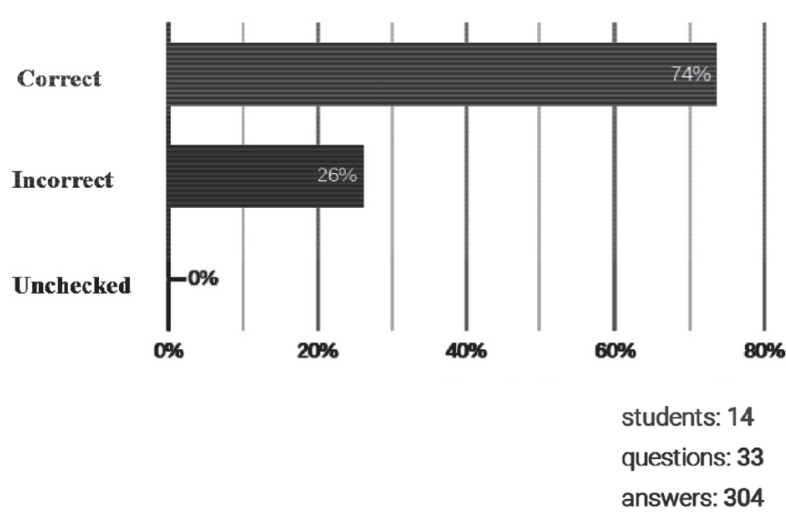

Fig. 3. Group test results

The analysis of the answers to each test task gives an opportunity to determine which questions are understood better by the students and which ones need further clarification (Fig. 4).

Statistics of test results, successful attempts, average succeed on each question allows the teacher to analyze the content and, if needed make the necessary changes to the tasks themselves.

Simple transformations...

$\checkmark$ do not change the rank of the matrix
$\times \quad$ increase the rank of the matrix

$\times$ decrease the rank of the matrix $25 \%$

$\times$ convert the rank of the matrix to zero $0 \%$

Fig. 4. Test results on each task in PDF format
Show names

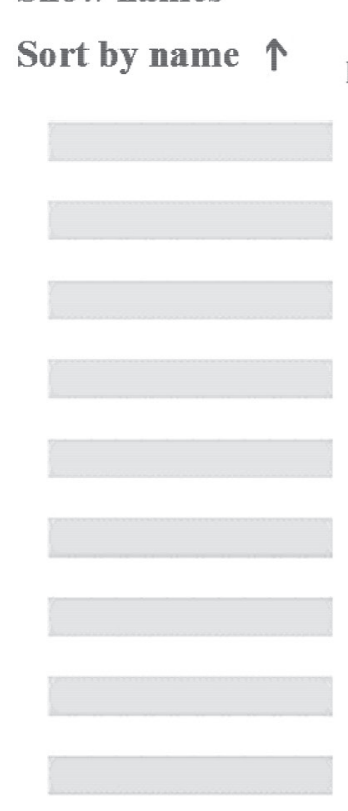

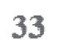

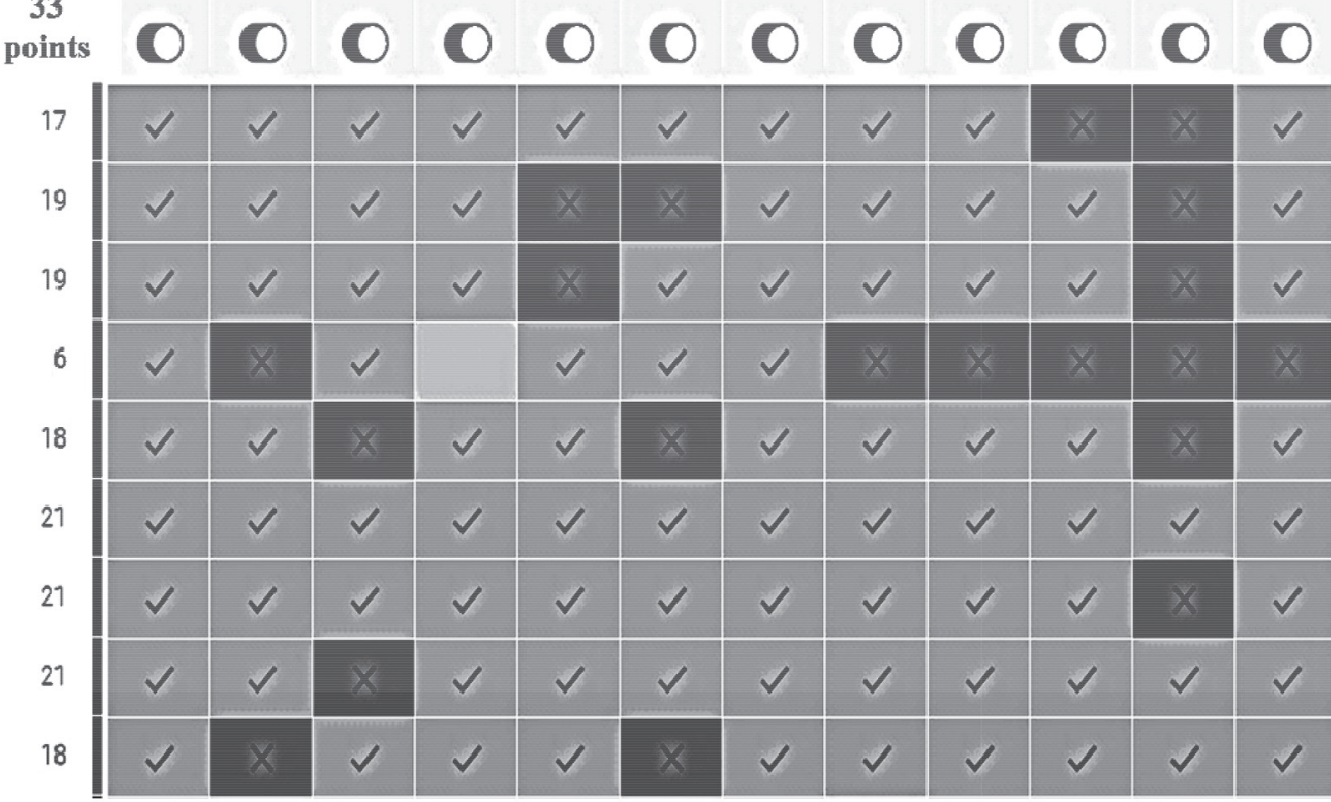

Fig. 2. Online test grades 


$\begin{array}{lll}\begin{array}{l}\text { Question 7 } \\ \text { choice }\end{array} & \text { Points } & \text { Simple transformations... } \\ \text { Student name } & 1 & \text { O O X O } \\ \text { Student 1 } & 0 & \text { O X O O } \\ \text { Student 2 } & 1 & \text { O O X O } \\ \text { Student 3 } & 0 & \text { X O O O } \\ \text { Student 4 } & 0 & \text { X O O O } \\ \text { Student 5 } & 0 & \text { OX O O } \\ \text { Student 6 } & 1 & \text { O O X O } \\ \text { Student 7 } & 1 & \text { O O X O } \\ \text { Student 8 } & 0 & \text { X O O O } \\ \text { Student 9 } & 1 & \text { O O X O } \\ \text { Student 10 } & 0 & \text { OX O O }\end{array}$

Fig. 5. Test results on each task in Excel format

Using Classtime platform, the teacher can track the individual trajectory of the student's learning achievements (Fig. 6), ie from what topics and sections he or she has completed tasks, student's learning pace, the order of the topics learned by a student, which topics or tasks caused difficulties. Being based on these data, the teacher can offer some advice to the student or give recommendations for the repetition of insufficiently studied material in order to deepen the knowledge of problematic topics.

The platform opens up great opportunities for analyzing each student's learning activities, determines the need for additional explanation and correcting actions by the teacher depending on the actual state of material learning.

Modern information technologies in the educational process are a means of improving the quality of mathematical training for higher education students in the conditions of inclusion and have several advantages for both teachers and students (Nosenko, 2018, pp. 28). The experience of using Classtime platform gives the following benefits for the teacher:
- saving time by using completed tests or developing one test for all students;

- keeping track of each student's educational progress and adjusting it as needed;

- providing special educational needs for all studentss;

- automatizing of knowledge assessment process;

- possibility to continuously improve learning courses on the basis of analysis of educational progress, peculiarities of passing of an individual trajectory by each student, which contributes to improvement education quality in HEI.

For higher education students the benefits of using Classtime platform are:

- equal conditions for passing the test through performing the same tasks by all participants and compensating for disorders of psychophysical development;

- self-analysis, control and self-correction made by the students, individual educational route, progress in the learning process through online feedback;

- possibility of passing the test outside the classroom;

- individual pace of completion of the test tasks.

Conclusions. Classtime platform usage helps adapt the process of mathematics teaching to specific educational needs and implement an individual approach to all higher education students, by partially compensating for functional limitations caused by certain diseases, for example, for people with visual impairments - the ability to increase the size of the task text, for people with hearing impairments maximum visualization of the test, for people with disorders of the musculoskeletal system - the ability to focus more on thinking due to the simplicity of answer choice and there is no need to write it but only clicking.

For communication purposes the platform makes it possible to communicate with students who cannot attend classes due to illness and they have the chance to learn the course distantly.

\begin{tabular}{|c|c|c|c|c|c|c|c|c|c|c|c|c|c|}
\hline Scores & $\%$ & Points & Q1 & Q2 & Q3 & Q4 & Q5 & Q6 & Q7 & Q8 & Q9 & Q10 & Q11 \\
\hline Student name & $100 \%$ & 11 & 1 & 1 & 1 & 1 & 1 & 1 & 1 & 1 & 1 & 1 & 1 \\
\hline Student 1 & $82 \%$ & 9 & 1 & 1 & 1 & 1 & 1 & 1 & 0 & 0 & 1 & 1 & 1 \\
\hline Student 2 & $91 \%$ & 10 & 1 & 1 & 1 & 1 & 1 & 1 & 1 & 1 & 1 & 1 & 0 \\
\hline Student 3 & $18 \%$ & 2 & 1 & 0 & 0 & 1 & 0 & 0 & 0 & 0 & 0 & 0 & 0 \\
\hline Student 4 & $64 \%$ & 7 & 0 & 1 & 1 & 1 & 1 & 1 & 0 & 0 & 0 & 1 & 1 \\
\hline Student 5 & $73 \%$ & 8 & 1 & 1 & 1 & 0 & 1 & 0 & 0 & 1 & 1 & 1 & 1 \\
\hline Student 6 & $55 \%$ & 6 & 1 & 1 & 0 & 1 & 0 & 0 & 1 & 0 & 1 & 0 & 1 \\
\hline Student 7 & $55 \%$ & 6 & 1 & 1 & 0 & 1 & 1 & 0 & 1 & 0 & 0 & 1 & 0 \\
\hline Student 8 & $27 \%$ & 3 & 0 & 0 & 0 & 1 & 0 & 1 & 0 & 1 & 0 & 0 & 0 \\
\hline Student 9 & $82 \%$ & 9 & 1 & 1 & 1 & 1 & 1 & 1 & 1 & 0 & 0 & 1 & 1 \\
\hline Student 10 & $27 \%$ & 3 & 1 & 0 & 0 & 0 & 1 & 0 & 0 & 0 & 0 & 0 & 1 \\
\hline
\end{tabular}

Fig. 6. Total test results 
The main tasks that can be solved with the help of Classtime in the process of mathematical preparation of higher education students in inclusive education are:

- determination of the initial level of students' mathematical preparation when they begin to study at HEI;

- monitoring learning activity of each student;

- analysis and correction of learning progress.

So the usage of modern Internet resources is scientifically grounded and pedagogically appropriate, learning platforms take into account the specifics of different functional limitations of higher education students and that will allow them to fully participate in the educational process and create conditions for the implementation of their individual educational trajectories. Turning to the problem of providing quality education for each participant in the educational process in accordance with his/her needs and opportunities, it should be noted that the development of methods of teaching mathematics in the conditions of inclusion with the use of ICT and creation of appropriate educational and methodological support

will have a perspective.

\section{List of references}

Classtime, 2019. [online] Доступно: <https://www.classtime.com> [дата звернення 24 Вересень 2019].

Верховна рада України. Законодавство України, 2019. Про затвердження Порядку організаиії інклюзивного навчання у закладах вищої освіти: Постанова Кабінету Міністрів Украӥни від 10 липня 2019p. №635. [online] Доступно: <https://zakon.rada.gov.ua/laws/show/635-2019-п> [Дата звернення 24 Вересень 2019].

Носенко, Ю. Г. ред., 2018. Сучасні засоби ІКТ підтримки інклюзивного навчання: навчальний посібник. Полтава: ПУЕТ.

Міністерство освіти і науки України, 2018. Деякі питання проведення в 2019 роиі зовнішнього незалежного оцінювання результатів навчання, здобутих на основі повної загальної середньої освіти: наказ М-ва освіти і науки України від 22.08.2018p. №931. [online] Доступно: <https://mon.gov.ua/ua/npa/deyaki-pitannya-provedennya-v-2019roci-zovnishnogo-nezalezhnogo-ocinyuvannya> [Дата звернення 24 Вересень 2019].

Осадча, К. П., 2017. Тьюторський супровід навчання математики засобами інформаційно-комунікаційних технологій. Інформаційні технології $і$ засоби навчання, [online] 61(5). Доступно: <https://www.researchgate.net/ publication/326266154_Tutorskij_suprovid_navcanna_matematiki_zasobami_informacijno-komunikacijnih_tehnologij> [Дата звернення 24 Вересень 2019].

Семеріков, С. О. та Словак, К. І., 2011. Теорія і методика застосування мобільних математичних середовищ у процесі навчання вищої математики студентів економічних спеціальностей. Інформаційні технології $i$ засоби навчання, [online] 1 (21). Доступно: <http://lib.iitta.gov.ua/106669/1/Теорія\%20та\%20методика\%20 застосування\%20 мобільних\%20математичних.pdf> [Дата звернення 24 Вересень 2019].

\section{Translated \& Transliterated}

Classtime, 2019. [online] Доступно: https://www.classtime.com [Data zvernennia 24 Veresen 2019], [in Ukrainian].

Verkhovna Rada Ukrainy. Zakonodavstvo Ukrainy [Verkhovna Rada of Ukraine. Legislation of Ukraine], 2019. Pro zatverdzhennya Poryadku orhanizatsiyi inklyuzyvnoho navchannya u zakladakh vyshchoyi osvity: Postanova Kabinetu Ministriv Ukrayiny vid 10 lypnya 2019r. №635 [On Approval of the procedure for Organizing Inclusive Education in higher education institutions: Resolution of the Cabinet of Ministers of Ukraine of July 10, 2019]. [online] Dostupno: <https:// zakon.rada.gov.ua/laws/show/635-2019-p> [Data zvernennia 24 Veresen 2019], [in Ukrainian].

Nosenko, Yu. H. red., 2018. Suchasni zasoby IKT pidtrymky inkliuzyvnoho navchannia: navchalnyi posibnyk. Poltava: PUET [Modern ICT tools to support inclusive learning: a manual]. Poltava: PUET, [in Ukrainian].

Ministerstvo osvity i nauky Ukrainy [The Ministry of Education and Science of Ukraine], 2018. Deiaki pytannia provedennia v 2019 rotsi zovnishnoho nezalezhnoho otsiniuvannia rezultativ navchannia, zdobutykh na osnovi povnoi zahalnoi serednoi osvity: nakaz M-va osvity i nauky Ukrainy vid 22.08.2018r. №931. [Some issues of external independent evaluation of learning outcomes based on complete general secondary education in 2019: Order of the Ministry of Education and Science of Ukraine from 22.08.2018]. [online] Dostupno: <https://mon. gov.ua/ua/npa/deyaki-pitannya-provedennyav-2019-roci-zovnishnogo-nezalezhnogo-ocinyuvannya> [Data zvernennia 24 Veresen 2019], [in Ukrainian].

Osadcha, K. P., 2017. Tiutorskyi suprovid navchannia matematyky zasobamy informatsiino-komunikatsiinykh tekhnolohii [Tutorial support of teaching mathematics by means of information and communication technologies]. Informatsiini tekhnolohii i zasoby navchannia [Information technology and training tools], [online] 61(5). Dostupno: <https:// www.researchgate.net/publication/326266154_Tutorskij_suprovid_navcanna_matematiki_zasobami_informacijnokomunikacijnih_tehnologij> [Data zvernennia $2 \overline{4}$ Veresen 2019$]$, [in Ükrainian].

Semerikov, S. O. ta Slovak, K. I., 2011. Teoriia i metodyka zastosuvannia mobilnykh matematychnykh seredovyshch u protsesi navchannia vyshchoi matematyky studentiv ekonomichnykh spetsialnostei. Informatsiini tekhnolohii i zasoby navchannia [Theory and methodology of application of mobile mathematical environments in the process of teaching higher mathematic to students of economic specialties], [online] 1 (21). Dostupno: <http://lib.iitta.gov.ua/106669/1/ Teoriia\%20ta\%20metodyka\%20zastosuvannia\%20mobilnykh\%20matematychnykh.pdf> [Data zvernennia 24 Veresen 2019], [in Ukrainian]. 


\section{Використання платформи Classtime в умовах інклюзії}

\section{Людмила Сидорук,}

аспірант кафедри педагогіки та управління навчальним закладом Кам’янець-Подільського національного університету імені Івана Огієнка, викладач математики кафедри інформаційної діяльності, документознавства і фундаментальних дисциплін Подільського спеціального навчально-реабілітаційного соціально-економічного коледжу

\section{Реферат.}

Актуальність: необхідність забезпечення рівних прав та створення можливостей для навчання осіб із різними освітніми потребами на всіх освітніх рівнях, зокрема й у вищій освіті. Зазначено, що питання реалізації наступності освіти та безперервного навчання впродовж усього життя зумовлюють потребу в науковому, методичному i технічному забезпеченні освітнього процесу закладів вищої освіти в умовах інклюзії.

Mema: аналіз можливостей сучасного Інтернет-ресурсу - платформи Classtime, з точки зору адаптації процесу навчання математики до індивідуальних потреб і можливостей здобувачів вищої освіти в умовах інклюзії.

Методи: аналіз і синтез - з метою з'ясування стану та рівня розробленості досліджуваної проблеми; узагальнення - для формулювання висновків щодо врахування специфіки різних функціональних обмежень здобувачів вищої освіти та створення умов для реалізації їх індивідуальних освітніх траєкторій за рахунок використання сервісу Classtime.

Результати. На основі досвіду використання платформи Classtime визначено, що цей сервіс дає змогу підвищити якість математичної підготовки здобувачів вищої освіти в умовах інклюзії і має ряд переваг як для викладачів так і студентів. Ресурс відкриває широкі можливості для аналізу навчальної діяльності кожного студента, визначення необхідності додаткового поясненння та коригування дій з боку викладача залежно від реального стану опанування матеріалом. Доведено, що застосування платформи Classtime сприяє адаптації процесу навчання математики до особливих освітніх потреб та реалізації індивідуального підходу до всіх здобувачів вищої освіти за рахунок часткової компенсації функціональних обмежень, зумовлених певними захворюваннями. Наприклад, для осіб із вадами зору - можливість збільшення розміру тексту завдання до потрібних розмірів, для осіб з порушеннями слуху - максимальна візуалізація тесту, для осіб з порушеннями опорно-рухового апарату - можливість зосередити більше уваги на обдумуванні завдання, завдяки простоті вибору правильної відповіді та відсутності необхідності записувати їі.

Висновки. Науково обгрунтоване та педагогічно доцільне використання сучасних Інтернет-ресурсів на основі врахування специфіки різних функціональних обмежень здобувачів вищої освіти, дасть їм змогу повноцінно включитися в освітній процес і створить умови для реалізації їхніх індивідуальних освітніх траєкторій. Перспективу має розроблення методики викладання математики в умовах інклюзії з використанням інформаційно-комунікаційних технологій і створення відповідного навчально-методичного забезпечення.

Ключові слова: інформаційно-комунікаџійні технологї̈; Інтернет-ресурси; математична підготовка; вища освіта; інклюзивне навчання; індивідуальні потреби і можливості. 